\title{
Antropojenik İklim Değişikliği Bağlamında Göç Tartışmaları*
}

\author{
Merve Suzan Ilık Bilben ${ }^{1}$
}

\section{Öz}

Insanlar her çağda çevresel değişimlere ya da iklim değişikliğine tepki olarak yer değiştirmişlerdir. Zira hareket etmek tehditten kaçmayı ve dayanıklılığı artırmayı sağlayan (özellikle planlandığında), değişime uyumun geleneksel ve olağan bir parçasıdır. Nitekim göç neredeyse insanın kendisiyle yaşıt ve dünyadaki insanlar tarafindan yaygın olarak değişen çevresel koşullara uyum sağlamak adına kullanılan geleneksel bir mekanizma olarak iklim değişikliği ile başa çıkma noktasında çözüm yollarından biri olabilir. İklim değişikliğiyle tetiklenen yer değiştirmelerin "yeni" olan tarafi ise, onun altında yatan antropojenik temelleri, çok sayıda insanın iklim değişikliğine olan şüpheli yaklaşımı ve iklim değişikliğinin göreceli gerçekleşme hızıdır. Bu makalenin amacı, antropojenik iklim değişikliğinin göç hareketleri, türleri ve düzenleri üzerindeki etkisine ilişkin tartş̧maları çok boyutlu bir şekilde ele almak ve bu sayede iklim değişikliği, çevre ve göç arasındaki karmaşık etkileşimi analiz etmenin önemini ortaya koymaktır. Bu amaçla literatür taramasına dayalı olarak gerçekleştirilen bu betimsel çalışma, iklim değişikliği kaynaklı göç konusunda genel bir çerçeve çizmektedir. İklim değişikliğinden etkilenecek toplumları da kapsayan geniş ve katılımcı süreçler oluşabilmesi adına küresel inisiyatif ve iştirakler kadar yerel düzeyde danışma, bilgilendirme ve kapasite geliştirme çalışmalarının güçlendirilmesi gerektiği vurgulanmaktadır.

\section{Anahtar Kelimeler}

Küresel ısınma • İklim değişikliği • Çevresel göç • İklim mültecileri

\footnotetext{
* Bu makale 2017 yılının tamamlanan "Yeni Bir Küresel Problem, Eski Bir Başa Çıkma Mekanizması: Antropojenik İlim Değişikliği Kaynaklı Göç ve Türkiye” adlı Yüksek Lisans Tezinden türetilmiştir.

1 Sorumlu Yazar: Suzan Ilık Bilben (Arş. Gör.), Akdeniz Üniversitesi, Edebiyat Fakültesi, Sosyoloji Bölümü, Antalya, Türkiye. Eposta: mervesuzanilik@akdeniz.edu.tr
}

Atıf: Ilık Bilben, S. (2018). Antropojenik iklim değişikliği bağlamında göç tartışmaları. Sosyal Siyaset Konferansları Dergisi, 75, 237-268. http://dx.doi.org/10.26650/jspc.2018.75.0015 


\title{
Migration Discussions in the Context of Anthropogenic Climate Change
}

\author{
Merve Suzan Ilık Bilben ${ }^{1}$
}

\begin{abstract}
People have always migrated in response to environmental change. Movement is a traditional part of human life that allows people to escape from threat and increase resilience (especially when planned). Migration is used almost exclusively by humans to adapt to changing environmental conditions around the world, may be one of the solutions for dealing with climate change. The "new" side of shifts triggered by climate change is the underlying anthropogenic causes, the susceptible approach of many people to climate change, and the relative rapidity of climate change. The aim of this article is to address the multidimensional debate of the impact of anthropogenic climate change on migration movements, patterns, and volumes and to emphasize the importance of analyzing the complex interaction between climate change, environment, and migration. For this purpose, this descriptive study based on a literature review draws a general framework about the issue of migration caused by climate change. In the final section, it is emphasized that consultation, information, and capacity-building activities at the local level should be strengthened as much as global initiatives and participations in order to create large and participatory processes that include the societies that will be affected by climate change.
\end{abstract}

\section{Keywords}

Global warming $\bullet$ Climate change $\bullet$ Enviromental migration $\bullet$ Climate fefugees

1 Corresponding author: Suzan Ilık Bilben (Ress. Asst.), Akdeniz University, Faculty of Letters, Department of Sociology, Antalya, Turkey. Email: mervesuzanilik@akdeniz.edu.tr

To cite this article: llık Bilben, S. (2018). Migration discussions in the context of anthropogenic climate change. Sosyal Siyaset Konferansları Dergisi, 75, 237-268. http://dx.doi.org/10.26650/jspc.2018.75.0015 


\section{Extended Summary}

The international scientific community believes that anthropogenic climate change will be experienced throughout the world during the 21 st century. It is obvious that climate change will distort natural balances, such as sea level rise, deforestation, drought, and extreme weather events. All these effects are predicted to cause serious distress to people's settlement patterns, living conditions, food production, and health conditions. Consequently, it is obvious that these environmental events and the problems that result will cause a displacement that is both national and international in scale.

People have always migrated in response to environmental change. Movement is a traditional part of human life that allows people to escape from threat and increase resilience (especially when planned). The "new" side of shifts triggered by climate change is the underlying anthropogenic basis, the susceptible approach of many people to climate change, and the relative rapidity of climate change. These features of climate change are accompanied by the risk of clashing with people's conventional strategies of coping. Today's change is rapid because it is anthropogenic in origin; it is not natural and slow climatic change. It is outside of our perception of the rate of change of nature, so it is difficult to predict its effects. The fact that the number of displaced people is increasing as a result of climate change day by day makes it more difficult (as well as urgent) to create a definition with international validity.

Climate change migrants today are one of the most controversial issues in international law. Compulsory climate migrants are filtering through the cracks in international refugee and immigration policies, and there are intensive discussions whether the refugee definition should be expanded for climate refugees or whether other definitions should be found. The ability of countries and people to adapt to changing climate will also determine how environmental migration will take place in the future. Moreover, it would be misleading to think that the links between climate change, environmental degradation, and migration have a simple linear causality, because there is a very complex and intertwined relationship between migration and environment. In a globalizing world, the consequences and pathways of anthropogenic climate change make it important to analyze this complex and intertwined relationship in all its dimensions.

The aim of this article is to address the multidimensional debate on the impact of anthropogenic climate change on migration movements, patterns, and volumes and to emphasize the importance of analyzing the complex interaction between climate change, environment, and migration. For this purpose, this descriptive study based on a literature review draws a general framework on the issue of migration due to climate change. The study first deals with migration as a mechanism of adaptation to the changing climate 
conditions and the impact of climate change on migratory mobility. Variables related to the migration process originating from climate change are addressed, and this approach is considered as a possible solution at the point of coping with climate change.

The causal relationship between climate change and migration is evaluated in terms of voluntary-compulsory, long-term-short-term, temporary-permanent, and regional-international migration types. It focuses on the difficulties of researching and conceptualizing climate change-induced migration. Further, this article focuses on the underlying anthropogenic basis of recent environmental displacements, the reasons why climate change induces people to migrate, and the problems of putting forward a definition. The scope of the definitions used in the literature is addressed as well as the empirical and conceptual difficulties in pointing out the establishment of a causal link.

In the last section, the effects of slow-onset and sudden climate events on migration movements, patterns, and densities are explained and climate change is discussed as a threat multiplier to socioeconomic and political distress. In this section, which refers to the obstacles facing quantitative predictions and the acquisition of statistics, it is emphasized that the groups most affected by climate change migration are disadvantaged groups located in vulnerable, mostly underdeveloped countries. Finally, the possibility of emerging new migration patterns is emphasized. Furthermore, it is emphasized that the consultation, information, and capacity building activities at the local level should be strengthened as much as global initiatives and participation in order to create large and participatory processes that include the societies that will be affected by climate change. 


\section{Antropojenik İklim Değişikliği Bağlamında Göç Tartışmaları}

Göçebeler dünya medeniyetlerinin oluşumunda büyük rol oynamışlardır. Her uygarlık kendi iç dinamiklerine göre farklı göç hareketleri meydana getirse de tüm bu hareketlerin ortak noktası göçlerin her uygarlığın kendi habitusunu genişletmesini sağlamış olmasıdır. Coğrafya ve iklim tarafindan dayatılan tüm sınırlamalara rağmen, göç her bir oluşumu alabildiğince uzaklara kadar genişletmiştir. Diğer yandan göç, tarihsel değişimin anahtar enstrümanlarından biridir. Göç akımları imparatorluklar yaratmış ve yok etmiş, güç dengelerini etkilemiş, geniş bölgelerin etnik ve kültürel kompozisyonlarını değiştirmiş, bazı gelişmeleri mümkün kılmış bazılarını ise tarihinin çöplüğüne terk etmiştir. İklim ve insan göçü arasında bir bağlantı olduğuna dair tarihsel kanıtlar mevcuttur. Ancak bu ilişki diğer toplumsal süreçlerle de yakından bağlantılıdır. Göç iklimle ya da diğer herhangi bir faktörle ilgili mevcut bir riske verilen basit ve otomatik bir tepki olarak düşünülmemelidir. İnsanın mekânsal davranışının ortaya çıkmasında birçok faktör bir araya gelir ve göç hassasiyetleri ile tercihleri sosyal gruplar ve bölgeler arasında büyük farklılıklar gösterir (McLeman ve Smit, 2006, s. 32).

Çevresel değişimler sonucu ortaya çıkan insan hareketliliği yeni bir olgu değildir. İnsanlar yüzyıllardır çevrelerindeki değişimlere bağlı olarak özellikle mevsimsel göç etmektedirler. Ne var ki, uluslararası toplum 20. yüzyılın ikinci yarısından sonra iklim değişikliğinin ve çevrenin insan hareketliliği üzerindeki etkisine dair geniş bağları ve etkileri tanımaya başlamıştır (Laczko ve Aghazarm, 2009, s. 13). İster bölgesel ister küresel olsun değişen iklim koşullarının ilgili yerlerde yaşayan popülasyonların hareketlilikleri üzerinde etkileri olduğu bilinmektedir. Nitekim literatürde tarih öncesi ve klasik dönemlerde iklim değişkenliği nedeniyle meydana gelen göç hareketlerini ve 20. yüzyılda meydana gelen iklim olaylarının neden olduğu göçleri inceleyen çalışmalar mevcuttur (McLeman, 2013, s. 600). ${ }^{2}$ Zira hareket etmek tehditten kaçmayı ve dayanıklılığı artırmayı sağlayan (özellikle planlandığında), değişime uyumun geleneksel ve olağan bir parçasıdır. İklim değişikliğiyle tetiklenen yer değiştirmelerin "yeni” olan tarafı ise, onun altında yatan antropojenik temeller, çok sayıda insanın iklim değişikliğine olan şüpheli yaklaşımı ve iklim değişikliğinin göreceli gerçekleşme hızıdır (McAdam, 2011, s. 3). Karş1

2 Bu çalışmalar için bakınız: McLeman, 2013, s. 600. 
karşıya olunan iklim değişikliğinin bu özellikleri, insanların geleneksel başa çıkma stratejilerinin de bir yerde tıkanma riskini beraberinde getirmektedir. Çünkü doğal ve olağan bir iklimsel değişimden değil, antropojenik kaynaklı ve doğanın değişim hızı algısından oldukça uzak, etkileri kestirilemeyecek düzeyde hızlı bir değişim söz konusudur.

Bu makalenin amac1, antropojenik iklim değişikliğinin göç hareketleri, türleri ve düzenleri üzerindeki etkisine ilişkin tartışmaları çok boyutlu bir şekilde ele almak ve bu sayede iklim değişikliği, çevre ve göç arasındaki karmaşık etkileşimi analiz etmenin önemini ortaya koymaktır. Bu amaçla literatür taramasına dayalı olarak gerçekleştirilen bu betimsel çalışmada, iklim değişikliği kaynaklı göç konusunda genel bir çerçeve çizilmektedir. Çalışmada öncelikle iklim değişikliğinin göç hareketliliği üzerindeki etkisi ve değişen iklim koşullarına bir uyum mekanizması olarak göç ele alınmaktadır. İklim değişikliği kaynaklı göç sürecine ilişkin değişkenlere değinilmekte ve göçe iklim değişikliği ile başa çıkma noktasında muhtemel bir çözüm olarak yaklaşılmaktadır. Kavramsal tartışmalara ilişkin ikinci bölümde, uluslararası göç tartışmalarında çevresel faktörlere olan ilginin izlediği tarihsel sürece değinilmekte; iklim değişikliği ve göç arasındaki nedensel ilişki gönüllü-zorunlu, uzun vadeli-kısa vadeli, geçici-kalıcı, bölgesel-uluslararası gibi göç türleri açısından değerlendirilmektedir. Ayrıca iklim değişikliği kaynaklı göçü araştırmanın ve kavramlaştırmanın güçlükleri üzerinde durulmaktadır. İklim değişikliği kaynaklı yer değiştirmelerin yeni olan tarafının, onun altında yatan antropojenik temeller olduğu üzerinde duran üçüncü bölümde, iklim değişikliği nedeniyle göç eden insanların nasıl tanımlanabileceği, dahası bir tanım ortaya konulamamasının nedenleri tartışılmaktadır. Literatürde kullanılan tanımlamaların kapsamlarına değinilmekte, bir sebep sonuç bağının ortaya konamamasındaki ampirik ve kavramsal zorluklar işaret edilmektedir.

İklim değişikliğinin göçe neden olan sosyo-ekonomik ve politik sıkıntılar için bir tehdit çarpanı görevi gördügüü üzerinde durulan son bölümde ise yavaş başlangıçlı ve ani iklim olaylarının göç hareketleri, düzenleri ve yoğunlukları üzerindeki etkisi anlatılmaktadır. Kantitatif öngörülerin ve istatistiklerin elde edilmesinin önündeki engellere değinilen bu bölümde iklim değişikliği kaynaklı göçlerden en çok etkilenen grupların savunmasız durumda bulunan, çoğunlukla az gelişmiş ülkelerde konumlanan dezavantajlı gruplar olduğu 
vurgulanmaktadır. Son olarak, iklim değişikliğinden etkilenecek toplumları da kapsayan geniş ve katılımcı süreçler oluşabilmesi adına küresel inisiyatif ve iştirakler kadar yerel düzeyde danışma, bilgilendirme ve kapasite geliştirme çalışmalarının güçlendirilmesi gerektiği vurgulanmaktadır.

\section{Antropojenik İklim Değişikliği ve Göç̧3}

Uluslararası bilim dünyasında 21. yüzyıl boyunca dünya üzerinde antropojenik iklim değişikliği yaşandıği ve yaşanmaya devam edeceği konusunda önemli bir konsensüs sağlanmıştır. Söz konusu iklim değişikliğinin doğal dengeleri bozarak, deniz seviyesi yükselmesi, ormansızlaşma, kuraklık ve uç hava olayları gibi etkileri olacağı oldukça açıktır. Tüm bu etkilerin insanların yerleşme şekilleri, yaşam koşulları, gıda ve su güvenliği- sağlık koşulları üzerinde ciddi sıkıntılar yaratacağı da öngörülmektedir. Bunun sonucunda yaşanacak tüm bu çevresel olaylar ve bunlara bağlı oluşacak problemlerin ulusal ve uluslararası ölçekte büyük oranda yer değiştirmelere neden olacağı aşikârdır. İklim değişikliği kaynaklı göç tartışmaları, Hükümetlerarası İklim Değişikliği Paneli’nin (IPCC) 1990 yılında yayınladığı etki değerlendirme raporunda "iklim değişikliğinin en büyük etkilerinin insan göçü üzerinde olabileceği”" (IPCC, 1990) öngörüsünde bulunduğu günden beri sürmektedir. Özellikle 2007 yılında yayınlanan IPCC'nin dördüncü rapor ile birlikte oldukça dikkat çekmiştir. IPCC'nin 2014 yılında yayınladığı raporunda ise iklim değişikliğinin yerinden edilen insan sayısını artıracağı vurgulanmaktadır (IPCC, 2014a, s. 16). Uluslararası Göç Örgütü’nün (IOM) göç, çevre ve iklim değişikliğine yaklaşımını şu şekilde özetlemek mümkündür (IOM, 2014a, s. 1):

a) Çevresel faktörler her zaman göçün bir nedeni olmuştur;

b) İnsanlar doğal felaketlerden kurtulmak için ya da sert ve bozulan çevresel koşullarla karşı karşıya kaldıkları zaman kaçarlar;

3 Bu noktada iklim değişikliği ile iklim değişkenliği arasındaki farkın altını çizmekte fayda vardır. İklim değişkenliği, insan etkisinden bağımsız, kendiliğinden gelişen bir süreci ifade etmek amacıyla kullanılan bir kavramken; iklim değişikliği, bu doğal değişkenliğin yanı sıra karşılaştır1labilir bir zaman diliminde -ki bu genellikle 30 y1l olarak kabul edilir- insan faaliyetleri sonucu meydana gelen değişimi ifade etmek için kullanılır. Lakin bu iki kavram sıkça birbirine karıştırılmakta, iklim değişkenliği kastedilerek iklim değişikliği kavramı kullanılmaktadır. Tam da bu sebeple bu makalenin başlı̆̆ında da bunu vurgulamak amacıyla antropojenik (insan kaynaklı) iklim değişikliği kavramı kullanılmıştır. Ek okuma için Bknz: Hulme, 2016. 
c) İklim değişikliğinin ani ve yavaş başlangıçlı felaketleri ve de aşamalı çevresel bozulmayı yoğunlaştırması beklenmektedir;

d) Çevresel göç ister gönüllü olsun ister zorunlu, kolaylıkla ayırt edilemeyen vakaları içerir;

e) Göç nüfusun çevresel faktörlerle baş etmesine izin veren bir adaptasyon stratejisi olarak giderek daha fazla kabul görmektedir.

İklim değişikliğinin sonuçlarının göçü nasıl etkilediği sorusunun cevabı, toplulukların var olduğu sosyo-kültürel-politik-ekonomik çevrelerini, iklim değişikliğinin etkisini yaşayan insanların bilişsel süreçlerini; bireyin ve toplumun göçe ve göçün sonuçlarına ilişkin tutumlarını ve göçün cevap verebileceği iklim uyarılarının türünü anlamaktan geçmektedir (Kniveton vd., 2008, s. 57). İklim değişikliğinin insan hareketliliğini en az dört şekilde etkilemesi beklenmektedir (IOM, 2014b, s. 34):

a) Daha büyük, sık ve potansiyel olarak daha yoğun bir şekilde meydana gelen hava koşullarına bağlı doğal afetler- hem ani hem de yavaş başlangıçlı -insani acil durumlar ve artan nüfus hareketleri riskinin artmasına neden olabilir.

b) İklim değişikliği etkilerinin geçim, sağlık, gıda ve su güvenliği üzerindeki olumsuz sonuçları muhtemelen önceden var olan savunmasızlıkları daha da arttıracaktır. Kırsal alanlardaki hane halkı geliri düştüğünde, iklim değişikliği ile bağlantılı geçim sıkıntısı, bazı yerlerde dışa göç düzeylerinin düşük olmasına neden olabilir. Göç kaynak gerektirdiğinden, gitmek isteyen ama kaynak yetersizliğinden dolayı gidemeyen insanlar sıkışmış nüfusları oluşturacaktır.

c) Yükselen deniz seviyeleri, kıyı alanlarını ve alçakta bulunan adaları yaşanmaz hale getirebilir.

d) İklim değişikliği azalan doğal kaynaklar üzerinde rekabeti ve gerilimi daha da arttırabilir ve potansiyel olarak çatışmaya, dolayısıyla yerinden olmaya yol açabilir.

İklim değişikliğinin sonuçları her bölgede farklı etkiler yaratabilecek karmaşık bir çevresel süreçtir. Toplumların da tarihsel süreçte en az iklim değişikliğinin kendisi kadar karmaşık ve çok boyutlu kurumsal, sosyo-ekonomik, kültürel ve teknolojik süreçlere uyum sağlamak zorunda kaldığı bilinmektedir. Bu bağlamda yeni, 
bilinmez ve çeşitlilik gösteren iklim değişikliği sürecine uyumun da bu çerçevede düşünülmesi gerekmektedir. İşte bu noktada insanlık tarihi kadar eski uyum mekanizmalarından biri olan göç devreye girmektedir. İklim değişikliği uluslararası toplumda büyük bir endişe halini alırken, değişimin insani boyutlarından biri olan göç her geçen gün hem politika belirleyiciler hem de araştırmacıların artan bir biçimde ilgisini çekmektedir. Ancak bu alandaki bilgiler halen sınırlıdır ve etkilenen mekanizmalar, kişi sayısı ya da coğrafi bölgelere dair belirsizlikler mevcuttur. Diğer yandan çevrenin nüfus hareketleri üzerindeki doğrudan etkisini vurgulayanlar ile bu hareketlerin daha çok sosyal, ekonomik ve politik bağlamlarda ortaya çıktığı üzerinde duranlar arasındaki tartışmalar sürmekte, her disiplin kendi girdisini literatüre dahil etmektedir (Piguet vd., 2011, s. 1).Yükselen deniz seviyesi, değișen yağış düzeni ve daha sık ve şiddetli firtınalar gibi iklim değişikliğinin meteorolojik etkilerini belirlemek için muazzam miktarda zaman ve enerji harcanırken, iklim değişikliğinin insan nüfusu üzerindeki etkilerinin ampirik analizi üzerinde çok daha az zaman, enerji ve kaynak harcanmaktadır (Brown, 2008, s. 12).

Antropojenik iklim değiş̧ikliğinin doğal afetlerin sıklaşması, gıda üretimini ve temiz suya ulaşımı etkileyen artan sıcaklık ve kuraklıklar, kaynaklar üzerinde artan rekabete bağlı çatışmalar, deniz seviyesi yükselmesine bağlı olarak batan adalar ve bozulan kıyılar gibi nedenlerle ciddi oranda insan hareketliliği yaratacağı öngörülmektedir. İklim değişikliği kaynaklı göç sürecine dair Piguet vd. (2011, s. 14-15) üç noktayı vurgulayarak ayrım yapmaktadır:

- Birinci ayrıma göre göç, kısa ya da uzun süreli olabilir. Göçün geçiciliği de çevresel süreçlerin doğası ile ilişkilidir: Çok sistematik bir tipoloji olmasa da genel anlamda çölleşme veya deniz seviyesi yükselmesi gibi yavaş başlayan olaylar uzun süreli göç ile ilişkili gibi görünürken, tropikal siklonlar gibi ani felaketler geçici yer değiştirmeler yaratacaktır.

- İkinci ayrıma göre göç, kısa mesafeli ve uzun mesafeli ya da iç ve dış hareketler şeklinde gerçekleşebilir. Her ne kadar iklim değişikliğine bağlı göç tartışmaları yoğunlukla «Güney»den «Kuzey»e uluslararası göç üzerine odaklanıyor olsa da kanıtlar çevresel faktörlerin tetiklediği göçlerin daha çok iç göç düzeyinde kaldığını göstermektedir.

- Üçüncü ayrım, zorunlu ve gönüllü göç arasındadır. Sıklıkla kullanılan «çevresel mülteci» kavramı, insanların doğal çevre yüzünden evlerini terk 
etmek zorunda kaldıkları fikrini ifade eder. Ne var ki, potansiyel göçmenler arasında karar alma sürecini yakalamak ve neden, nasıl ve ne zaman ayrılmaya karar verdiklerini ortaya koymak son derece zordur.

İnsan hareketliliğinin değişen iklimin sonuçlarından biri olduğunu savunanlar, fırtınalar, seller ve kasırgalar gibi iklim değişikliğinin ani etkilerinin ve ormansızlaşma, çölleşme ve kuraklık gibi aşamalı etkilerinin her ikisinin de toprağ 1 ve gida üretimini olumsuz etkilediği ve hatta çoğu durumda yok ettiğini iddia etmektedir (Okeowo, 2013, s. 276). Kuşkucular ise yaşanan çevresel felaketlerin insan etkinliğine bağlanamayacağını veya en azından yaşanan her felaketten antropojenik iklim değişikliğinin sorumlu tutulamayacağını dolayısıyla bunların sonucunda meydana gelen göç hareketlerinin bu bağlamda değerlendirilmemesi gerektiğini savunmaktadırlar. Zira tarih doğal felaketler nedeniyle yerinden olan binlerce topluluğun örnekleriyle doludur. Ne var ki, sanayi devriminden bugüne yaşanan süreçte insan faaliyetleri sonucunda yaşanan iklim felaketlerinin sayısının oldukça arttığı bilinmektedir. Bu bağlamda iklim değişikliğinin yarattığı daha sıcak ve daha kuru bir iklim ${ }^{4}$, daha değişken bir yağış düzeni, artan ve uzayan kuraklıklar sonucu yayılan çölleşme ve azalan gıda üretimi gibi etkileri sonucunda insan hareketliliğinin artacağ 1 tahmin edilmektedir (Okeowo, 2013, s. 277). IOM, çevresel ve iklimsel değişiklikler bağlamında insan hareketliliği konusunda etkin eylem için dört önemli noktaya değinmektedir (IOM, 2014b):

a) Çevresel ve iklim değişikliği kaynaklı göç, çok kutuplu ve çok boyutlu bir olgudur. Çevresel ve iklimsel faktörler hem itici hem de çekici faktörlerdir ve bunlara ekonomik, sosyal, politik ve demografik yönlerden aracılık edilmektedir. Tüm bu farklı boyutlar birlikte bir topluluk ve bir kişinin dayanıklılığı ve savunmasızlığını tanımlar. Göç, çevre ve iklim değişikliği ilişkisi «çift duyarlılık sorunu» oluşturmaktadır. Şöyle ki, iklim müzakereleri siyasi açıdan hali hazırda hassas bir konu iken, çevresel kaynaklı göç ile ilgili sorular incelendiğinde daha da hassas bir hal almaktadır. Benzer şekilde, göç son derece karmaşık bir konudur ve devletlerarası göç konusundaki iş birliği hassasiyetleri devam etmektedir.

4 1983-2012 yılları arası Kuzey Yarım Küre'de son 1400 yılın en sıcak 30 yıllık dönemi olarak kayıtlara geçmiştir (IPCC, 2014a, s.2). Ayrıca 2017 y1lı itibariyle dünyanın ortalama sıcaklığ 1 sanayi öncesi döneme göre tam $1^{\circ} \mathrm{C}$ artmıştır, daha detaylı veriler için bknz: IPCC, 2018. 
b) İklim değişikliği bağlamında göçten bahsetmek, iklim değişikliği tartışmalarının insani yüzüne bakmak demektir. Göçmenlerin kendileri, aileleri ve topluluklarına; stratejilerini ve hareket kabiliyetlerini anlamak için daha fazla önem verilmelidir. Politika yapıcıların, göç, çevre ve iklimin karmaşık bağını ele alabilmek için, yerel veya bölgesel, ulusal ve uluslararası seviyelerde yetkilendirilmeleri gerekmektedir.

c) İnsan hareketliliği hem direnç hem de hassasiyet barometresi olarak okunabilir. Göçmenlerin hareket kabiliyet stratejileri doğası gereği sadece olumlu ya da olumsuz değildir. Hareketlilik, hayatları kurtarabilir, dayanıklılığı artırabilir ve riski azaltabilir- aynı zamanda insanları savunmasız duruma düşürebilir ve onları yeni risklere maruz bırakabilir. Ayrıca etkilenen alanlardan çıkamamak da güvenlik açığını ortaya çıkarabilir; çünkü sıkışmış nüfus genellikle çevresel tehditlerle başa çıkmak için daha az seçeneğe sahiptir.

d) Göç, siyasi icraatlarla desteklenebilecek bir uyum seçeneğidir. Tarih, değişen çevre koşullarına uyum sağlamak için göçü kullanan bireylerin ve toplumların pek çok örneğini bize sunmaktadır. Bazı bağlamlarda, göç, siyasi icraatlarla desteklenebilen önemli ve olumlu bir uyum stratejisi oluşturabilir. Göçün hem mevcut hem de gelecekteki çevresel değişimlere uyum içerisinde ne şekilde cevap vereceğine ilişkin kanıt tabanının geliştirilmesi önemlidir.

Sosyal, politik, demografik ve ekonomik etkenlerle iç içe geçmiş, çok boyutlu ve çok nedenli bir olgu olarak göç, iklim değişikliği etkileri sonucu gerçekleşen göç sürecinin paydaşları açısından mutlak surette olumsuz bir anlam taşımamalıdır. Aksine belki de gelecekte etkileri kaçınılmaz bir biçimde öngörülen iklim değişikliğine bir cevap, bir tepki olarak geliştirilebilir. Zira göç neredeyse insanın kendisiyle yaşıt ve dünyadaki insanlar tarafından yaygın olarak değişen çevresel koşullara uyum sağlamak adına kullanılan geleneksel bir mekanizma olarak iklim değişikliği ile başa çıkma noktasında bir çözüm olabilir. Bu bağlamda zorunlu göçleri mümkün olduğunca azaltmak, engel olunamayan zorunlu göçlerden etkilenen insanlara gerekli yardımı ve korumayı sağlamak bu sürecin en önemli basamağıdır. İklim değişikliği ile çevresel bozulma ve iklim değişikliği ya da çevresel bozulma ile göç arasındaki bağlantıları araştırmak, iklim değişikliği etkilerinden dolayı yerinden edilmiş kişilerin korunması için oluşturulacak uygun platformun bir mülteci 
paradigması olarak $\mathrm{m} 1$ yoksa bir uyum stratejisi olarak $\mathrm{m} 1$ değerlendirilmesi gerektiği noktasında önem taşımaktadır (Okeowo, 2013, s. 275).

\section{Kavramsal Tartışmalar}

Her ne kadar çevresel göçler popülerlik kazanarak yeni bir alanmış gibi görülse de aslında Ravenstein (1889) başta olmak üzere literatürde tarihi daha eskilere dayanan bir göç türünden bahsedilmektedir. 20. yüzyıl boyunca göç literatüründe gittikçe kaybolan ve 1980'lerden itibaren yoğunlaşan uluslararası göç çalışmalarında da değinilmeyen çevresel faktörlere bu azalan ilgiyi Piguet vd. (2011, s. 3-4) dört eğilimle açıklamaktadır: Birincisi, Batı merkezli düşünceye göre teknolojik ilerleme doğanın insan hayatındaki etkisini azaltacaktır. İkincisi, göçün çevre temelli açıklamaları, sosyo-kültürel yaklaşımların veya Marksist / ekonomik perspektiflerin yararına olan sözde deterministik doğaları nedeniyle gittikçe reddedilmiştir. Üçüncü sebep, göç teorisinde ekonomik paradigmanın yükselişi ile beraber ekonomik faktörlere en merkezi rolün verilmesidir. Son olarak, zorunlu göç çalışmaları çevresel nedenlerle yerinden edilmeleri içerebilirken daha çok devlet ekseninde güçlü bir politik öncül üzerine inşa edilmiştir.

1980'lerin sonu 1990'ların başında iklim değişikliğine olan ilginin artması, muhtemel iklim göçmenleri ile ilgili ortaya atılan sayılar ve IPCC'nin 1990'da yayınladığı rapor ile konuya dikkat çekmesi sonucunda "çevresel göçmenler" tekrar tartışmalarda yerini almıştır. Ancak bu dönemde çevresel göçmenlerin, iklim değişikliği kaynaklı sebeplerden ötürü ülkelerini terk etmek zorunda kalacak olan insanlar olarak resmedilmesi ve mevcut göç akımlarının ampirik analizlerinden ziyade geleceğe dönük öngörüler temelinde gerçekleşmesi, çoğu göç araştırmacısının görüşüyle açıkça çelişmiş; doğa ve sosyal bilimciler arasında uzun zamandır süregelen bir bölünmeye yol açmıştır. Doğa bilimcileri çevresel bozulma ve göç arasındaki karşılıklı ilişkiyi kabul edip, ilişkili çok sayıda insan olduğunu vurgularken sosyal bilimciler ise çevreyi diğer birçok göç sürücüsünden biri olarak görüp öne sürülen tahminler konusunda oldukça temkinli yaklaşmaktadırlar (Piguet vd., 2011, s. 5). Bu tarz tartışmalar devam ediyor olsa da belirgin bir disiplin ayrımının ortadan kalktığını söylemek mümkündür. Göç uzmanları göç dinamiklerinde çevresel faktörlerin rolüne daha çok eğilmekteyken, çevre bilimciler de daha temkinli 
ve çok boyutlu yaklaşımlara açık hale gelmekte, son y1llarda iklim değişikliğinin sonuçlarının her zaman olduğundan daha sık ve sert bir biçimde kendini göstermesi ise ampirik çalışmalar için umut vaat etmektedir.

İklim değişikliği kaynaklı göç diğer tüm göç türleri gibi çok nedenli bir olgudur. Diğer bir deyişle, iklim değişikliği ve göç arasındaki ilişki basit bir nedensellik ilişkisi değildir. Her ne kadar halen daha ampirik kanıtlar zayıf kalsa da iklim değişikliği etkilerinin göç olgusu üzerinde belirgin ve artan bir etkisi olduğu gerçektir. Birçok göç türünde olduğu gibi iklim değişikliği kaynaklı göçler de gönüllü-zorunlu, uzun süreli-kısa süreli, geçici-kalıcı ya da bölgesel-uluslararası nitelikleri dolayısıyla çok yönlüdür. Bunun yanı sıra kır-kent göçü ve artan kentleşme tartışmaları iklim değişikliği bağlamında da oldukça önemlidir. İklim değişikliği kaynaklı göçleri sınıflandırmaya yönelik Ottowa Üniversitesi`nden Robert McLeman'ın çalışması daha genel bir ayrıma işaret etmektedir. McLeman iklim değişikliği bağlamında zorunlu göçleri iki sınıfa ayırmaktadır: İklim Olayları ve İklim Süreçleri (Brown, 2008, s. 17). İklim süreçleri, deniz seviyesi yükselmesi, tarım arazilerinin tuzlanması, çölleşme, artan su kıtlığı ve gıda güvensizliği gibi görece yavaş gerçekleşen değişimlerdir. Carteret ve Tuvalu adalarından deniz seviyesi yükselmesi nedeniyle gerçekleşen göçler ve Afrika>dan kuraklık ve su kıtlığı nedeniyle gerçekleşen göçler bu gruba örnek olarak verilebilir. Diğer taraftan iklim olayları ise seller, kasırgalar, firtınalar, tayfunlar gibi ani ve dramatik bir biçimde gerçekleşen değişimlerdir. Bu değişimlere bağlı olarak gerçekleşen zorunlu göçlere ise Amerika da meydana gelen kasirgalar yahut Asya>da meydana gelen seller sonucu gerçekleşen göçleri örnek olarak vermek mümkündür.

Diğer taraftan, iklim değişikliği kaynaklı göçleri konunun muhatabı olan grubun kırılganlık derecesine göre sınıflandırmanın önemine değinen Piguet vd. çalışmalarında birbiriyle bağlantılı iki ana argümanı tartışmaktadır. Birincisi, göçteki çevresel ve iklimsel faktörlerin ağırlığını ve sosyal, siyasi veya ekonomik nitelik taşıyan diğer itme veya çekme faktörleri ile olan ilişkisini göz önüne almaktadır. Buna göre iklim değişikliğinin göç dinamikleri üzerindeki rolünü anlayabilmek, insanların nasıl ve neden iklim değişikliğine karşı savunmasız olduklarının ve çevresel stresle baş etmek için geliştirdikleri farklı stratejilerin bir değerlendirmesini gerektirir. İkinci argüman, gerçekleşen göç akımlarına yönelik siyasi yaklaşım ve çevresel faktörlerle bağlantılı olarak 
hareket eden kişilere nasıl davranılması gerektiği ile ilgilidir. Bu, savunmasız durumda olanlara sağlanacak potansiyel koruma ve bu korumayı sağlayacak sorumlu olan hükümetler ve uluslararası toplum üzerine tartışmaları da beraberinde getirmektedir. İklim değişikliği etkilerinin göçü ne derece belirlediği konusu ve bu tür göçlerle ilişkilendirilecek insanların statüsüyle ilgili konu kuşkusuz iç içe geçmiş iki noktadır (Piguet vd., 2011, s. 2). Görüldüğü üzere içerdiği çok sayıda değişken nedeniyle iklim değişikliği kaynaklı göç hakkında tahminlerde bulunmak ve göç etme kararının ardındaki etkenler arasından iklim değişikliği etkilerini izole etmek oldukça zor bir uğraştır. Bu nedenle IOM, göçmenleri bir kategoride sınıflandırmaya çalışmak yerine, iklim değişikliği sonucu meydana gelen göçlerin azaltılmasında uyum ve esnekliğin sağlanması noktasında önemli bir araç olan "savunmasızlığı" kavramsal ve operasyonel çabaların merkezine koymaktadır (IOM, 2014b, s. 6).

\section{Yasal Boşluklar: Mülteci mi? Göçmen mi?}

Sadece 2017 yılında, 135 ülkede 18,8 milyon (seller nedeniyle 8,6 milyon, firtınalar nedeniyle 7,5 milyon) insan kendi ülkelerindeki ani başlangıçlı felaketler sonucu yerinden olmuştur. Bu, daha önceki felaketlerden sonra halihazırda yerinden edilmiş milyonlarca insana eklenen rakamdır zira 2008 ile 2016 yılları arasında 227,6 milyon insanın felaketler nedeniyle yerinden edildiği tahmin edilmektedir (IOM ve GMDAC, 2018, s. 44). Kurakl1klar ya da deniz seviyesi artışı gibi yavaş başlangıçlı süreçler, insanların hareketliliğini dünya çapında giderek daha fazla etkilemekle birlikte, sistematik ve kaliteli veriler mevcut değildir (IOM ve GMDAC, 2018, s. 45). ABD'de, İrma Kasırgası'nın yaklaşması, Florida valisinin Miami'de milyonlarca insanın tahliye edilmesini istemesine yol açmış ve Harvey kasırgası, on binlerce insanın yerinden edildiği Houston, Teksas'da ağır su baskınlarına neden olmuştur. Maria Kasırgası, Porto Riko adasını sert bir biçimde vurmuş, şehir merkezlerini, yolları ve iletişim altyapısını tahrip etmiş ve de on binlerce kişiyi yerinden etmiştir (IOM, 2017, s. 38).

Uluslararası Göç Örgütünün 2018 y1lı raporuna göre, 2008'den beri her y1l ortalama 25,3 milyon kişi felaketler nedeniyle yer değiştirmiştir. Bu, çatışma ve şiddet kaynaklı yer değiştirmelerin ortalamasından çok daha yüksektir ve tehlikelerin ayrım gözetmeyen, tahmin edilemez ve kontrol edilemez doğasını yansıtmaktadır. Bu boyutlar, yakın zamanda yerinden edilmiş insanlara ev sa- 
hipliği yapan ülkelerin sayıları dikkate alındığında da çarpıcı bir şekilde görülmektedir: afetler nedeniyle göç edenlere 118 ülke ev sahipliği yaparken, bu rakam çatışma ve şiddet kaynaklı göç edenler noktasında 37'dir. 2016 yılında sel ve firtınalar gibi felaketler nedeniyle göç edenlerin oranı toplam göç eden 24.2 milyonun 23,5 milyonunu yani \%97'sini oluşturmaktadır (IOM, 2017, s. 38).

Görüldügü üzere iklim değişikliğinin etkileri sonucunda yerlerinden olan insanların sayısı her geçen gün artmaktadır ve savunmasız durumda bulunan çok sayıda insanın karşılaşacağı tablonun artık daha net bir biçimde öngörülüyor olması uluslararası geçerliliğe sahip bir tanım oluşturmayı bir taraftan zorlaştırırken bir taraftan da oldukça ivedi kılmaktadır. İklim değişikliğinin çevresel etkileri nedeniyle göç etmek zorunda kalan insanların nasıl tanımlanacağı, hangi haklardan yararlanabileceği, hangi kapsamda değerlendirileceği ve nasıl bir korumaya sahip olacakları bugün literatürde en çok tartışılan konulardan biridir. Zira bu konu sadece bilimsel açıdan değil, genel kabul gören tanımın uluslararası toplumun uluslararası hukuktaki yükümlülüklerinin belirlenmesi açısından da büyük önem taşımaktadır (Brown, 2008: 13). Ayrıca, net ve anlaş1ır bir tanıma ulaşılmadığı takdirde, politika yapıcılar ve uygulayıcılar tarafından planların kolaylıkla ortaya koyulamayacağı ve hedeflenen ilerlemelerin kaydedilemeyeceği bir gerçektir (Dun ve Gemenne, 2008, s. 10).

Göçmen ve mülteci tanımlarındaki sıkıntılardan ötürü literatürde (ve bu çalışmada da) kişiden ziyade sürece odaklanan birçok farklı terimle karşılaşmak mümkündür. Bunlardan bazıları çevresel göç (environmental migration), çevresel yerinden edilme (environmental displacement), iklim göçü (climate migration), iklimsel yerinden edilme (climate displacement), çevresel kaynaklı göç (environmentally induced migration), iklim kaynaklı göç (climate-induced migration), çevresel hareketlillik (environmental mobility), iklim hareketliliği (climate mobility), çevresel hareketler (environmental movement) vb. şeklindedir (Nicholson, 2014, s. 153) ${ }^{5}$. Daha önceki tartışmalardan da anlaşılacağı üzere uygun ve kabul edilebilir bir tanım ortaya konulamamasının temel sebebi iklim değişikliği ve göç arasında bağın karmaşık doğasından kaynaklanmakta-

5 İklim kelimesi, küresel ısınma ve iklim değişikliği söylemi ile olan bağlantıyı vurgulamak için kullanılabilirken; bunun yerine, "çevre" terimi ise, küresel 1sınmayla tetiklenen göç ile doğal afetler (örn., döngüsel hava anormallikleri) ve çevresel bozulma (ör., doğal kaynakların fazla kullanılması) gibi diğer kaynaklar tarafından tetiklenen göçü ampirik olarak ayırmanın mümkün olmadığını vurgulamak için kullanılabilir (Faist ve Schade, 2013, s. 6). 
dır. Fırtına ve sel gibi ani ve aşırı hava olaylarını ele aldığımızda örneğin çevresel faktör barizdir ve göç hareketi açık bir biçimde zorunludur. Ancak iklim değişikliğinin bu tür hava olayları üzerindeki etkisinin ne kadar olduğunun net olarak ortaya konulması noktasında tartışmalar söz konusudur. Kuraklık ve su kıtlığı gibi iklim değişikliği kaynaklı çevresel bozulmaları ele aldığımız da ise sürece dâhil olan yapısal, sosyal ve ekonomik faktörler nedeniyle öncül sebebi (iklim değişikliğini) ayırt etmek zorlaşmaktadır. İklim değişikliği kaynaklı göçler noktasında en bariz ve tartışmasız vaka deniz seviyesi yükselmesi olarak görülse de bu durumda bile yerleşim yerlerinin sürdürülemez hale gelmesi ile birlikte ekonomik göç mevzu bahis olmaktadır.

Ne var ki, uygulanabilir koruma çözümleri geliştirmek, iklim değişikliği, çevresel koşullar ve göç arasındaki bağlantıların belirlenmesini gerektirmektedir. Ancak deterministik bir sebep-sonuç bağının ortaya konmasındaki ampirik ve kavramsal zorluklar oldukça derindir. Çünkü iklim değişikliğinin etkilerini diğer çevresel etkilerden ayırmak ne kadar zor ise, genel anlamda çevresel etkileri de sosyo-ekonomik ve politik süreçlerden ayırmak da bir o kadar zordur. Her ne kadar iklim değişikliği terimi belirli bir dönemde ortalama iklim koşullarındaki değişim olarak tanımlansa da çevresel değişimin zararlarından etkilenen bireylerin ya da grupların kurumsallaştırılmış bir koruma biçimine sahip olmaları adına iklim değişikliğinin, genel çevresel değişimin ve sosyo-bağlamsal etmenlerin birbirleriyle ilişkili olarak değerlendirilmesi gerektiği görülmektedir (Laczko ve Aghazarm, 2009, s. 393-394).

Uygun bir tanımlama yapılabilmesi noktasında zorunlu-gönüllü göç tartışması da önem taşımaktadır. Daha önce tartışılan çok nedenli ve çok boyutlu vakalar bir yana, bazı durumlarda iklim değişikliği ve göç arasındaki doğrudan bağlantı nedeniyle zorunlu göç kavramı öne çıkmaktadır. Örneğin uç hava olayları sonucu meydana gelen felaketler ya da azalan kaynaklar nedeniyle çıkan çatışmalar sonucu meydana gelen göçler buna bir örnektir. Ayrıca deniz seviyesi yükselmesine bağlı olarak adalarda meydana gelen uluslararası nitelik taşıyan göçler de kuşkusuz bu bağlamda değerlendirilebilir (Laczko ve Aghazarm, 2009, s. 396). Diğer taraftan iklim değişikliğine bağlı olarak gerçekleşen yavaş başlangıçlı çevresel bozulmaları ya da aşamalı değişimleri ise zaman içerisinde diğer etmenlerle iç içe girmeleri dolayısıyla zorunlu göç bağlamında değerlendirmek zorlaşmaktadır. 
Kamu sorunlarının oluşumunda çifte tanımsal bir süreç -yani problemlerin nedenlerini tanımlayan, problemin çözümünü sağlayacak olan sorumluyu açıklayan ve sorunun sonuçlarını tanımlayan ve kurbanların nasıl korunacağını belirleyen bir süreç- işlediğini ifade eden Vlassopoulos'a (2000, s. 118) atıf yapan Faist ve Schade (2013, s. 147), kamu sorunlarını şematik olarak 'neden-problem-sonuç-çözüm' ile birbirine bağlı dizilerin bir ardıllığı olarak sunmakta ve bu süreci şu şekilde örneklemektedir: (1) Endüstriyel üretim (neden), diğerlerinin yanı sıra, iklim değişikliği (sonuç) yaratan sera gazları (problem) üretir; (2) sera gazı emisyonlarından kaynaklanan iklim değişikliği (problem) kuraklığa neden olur (iklim değişikliğinin etkilerinin bir kısmı) (sonuç); (3) iklim değişikliğinin (neden) neden olduğu kuraklık (problem), (diğer olumsuz etkilerin yanı sıra) göçe yol açar (sonuç/çözüm) vb. Bu noktada küresel problemlere çözüm üretme kapasitesine sahip olan Birleşmiş Milletler (BM) öne çıkmaktadır. BM çerçevesinde iklim değişikliği ile ilgili kural ve programların geliştirilmesi ve uygulanmasından sorumlu olan birim Birleşmiş Milletler İklim Değişikliği Çerçeve Sözleşmesi'dir (BMIDCÇS). Devletleri kendi sınırları içerisinde harekete geçmeye ve küresel düzeyde diğer devletlerle görüşmeye ve hareket etmeye teşvik eden BMIDÇS, en savunmasız durumda olan ülkeler için bir ses olmakta, ayrıca hafifletme, kalkınma, insan hakları ve güvenlik konularını birbirine bağlama firsatı sunması dolayısıyla, iklim göçmenlerini tanımaya ve nihai olarak gelecekteki göç baskısını azaltmaya yardımcı olmaktadır (Gibb ve Ford, 2012, s. 3). BMIDÇS altında Cancun'daki 2010 Taraflar Konferansı'nda iklim değişikliğinin yol açtı̆̆ı yerinden olma, göç ve planlı yer değiştirme tanınırken, bu hareket kategorilerine kimlerin dâhil olduğu tanımlanmamıştır (Nishumura, 2015, s. 112).

İklim değişikliği nedeniyle yerinden edilenler için net bir tanım ortaya koymak uluslararası koruma sağlamanın ilk adımıdır. Bu noktada göç türleri bağlamında bir sınıflandırma yapmak birçok sorunu beraberinde getirir. Çünkü tek bir etmen, olay ya da süreç genellikle tek başına göçü doğurmaz. Çevresel değişimler göçün en temel tetikleyicilerinden biri olsa da göç kararı birçok sosyal, kişisel, ekonomik, kültürel ve politik etmenin etkileşimi ile oluşur. İklim değişikliğini bir neden olarak ayırmayı imkânsız kılan bu karmaşıklık, uluslararası kabul görmüş yasal bir iklim 〈göçmeni〉, 〈mültecisi〉 ya da 〈yerinden edilmiş bireyi〉 tanımının yokluğunda, etkilenen kişi sayısının tahmininde geniş tutarsızlıklar yaratmaktadır (Gibb ve Ford, 2012, s. 2). Di- 
ğer bir ifadeyle, problemin resmi bir tanıma henüz ulaşmamış olması (1951 Cenevre Sözleşmesinde siyasi mülteciler için yapılan tanım gibi) ve uluslararası politika gündemindeki yerinin kalıcı ve net bir şekilde bir şekilde henüz ortaya konulmaması-, tanımlama sürecini kendi inanç sistemleri, bilgileri ve/ veya politik yaklaşımları çerçevesinde etkilemeye çalışan taraflara büyük bir esneklik kazandırmaktadır (Faist ve Schade, 2013, s. 146).

Fikir birliğinin olduğu neredeyse tek konu mevcut terminolojilerin hemen hiçbirinin tek başına geçerli olmadığı ve yaygın kullanımının sıkıntılara yol açabileceğidir. Bununla birlikte göçün çevresel sürücülerle olan bağı nedeniyle bu hareketlerin ağırlıklı olarak zorunlu göç bağlamında değerlendirilmesi gerektiği varsayılmaktadır. İklim mültecileri ya da çevresel mülteciler terimlerine medyada s1klıkla yer verilmesi bu algıyla ilintilidir. En basit anlamıla insanların iklim değişikliğinin etkileri nedeniyle sığınma talebinde bulunacaklarını öne sürerek çevresel mülteci ya da iklim mültecisi terimlerini kullananların, konuya dikkat çekme ve meselenin aciliyetini ifade etme amacı taşıdıklarını söylemek mümkündür. Diğer tüm terminolojilerin konunun ciddiyetini göz ardı edeceğinden endişe duyulmaktadır. Çünkü "mülteci" vurgulanan baskı nedeniyle sempati uyandırırken "göçmen" daha gönüllü bir hareketi ima ederek daha "olumsuz” bir çağrışım yapmaktadır (Brown, 2008, s. 13).

İklim değişikliği kaynaklı göç tartışmaları uzunca bir dönem "çevresel mülteciler" tartışmaları üzerine inşa edilmiştir. 1970^lerde ilk kez Worldwatch Enstitüsü>nden Lester Brown tarafindan ortaya atılan (Saunders, 2000), on y1l sonra Birleşmiş Milletler Çevre Programında (UNEP) El-Hinnawi»nin çalışmalarıyla (1985) daha fazla bilinir hale gelen «çevresel mültecilere» ilişkin sayısal bilgilerin çoğu, Myers ve Kent (1995) tarafindan yapılan tahminlere dayanmaktadır (Kniveton vd., 2008, s. 29). Myers a göre genel olarak çevresel bozulma sonucu uluslararası göç etmek zorunda kalacak insanlar olarak tanımlanabilecek çevresel mülteciler, Jacobsen (1988) göre dünyada yerinden edilmiş insanlar arasında en büyük sınıfı oluşturabilecektir. Diğer yandan Cairns (2002) ise tüm insanların bir gün çevresel mülteci olabileceğini ifade ederek konuya dikkat çekmektedir (akt: Kniveton vd., 2008, s. 29). Çevresel göçmen terimi:

“...hayatlarını ya da yaşam koşullarını olumsuz bir biçimde etkileyen çevre koşullarında meydana gelen ani ya da aşamalı değişiklikler yüzünden mutat yerleşim yerlerini gerek geçici gerek daimî olarak terk etme zorunluluğu altında olan ya da 
terk etmek zorunda kalan ya da terk etmeyi tercih eden ve ülke içinde yer değiştiren ya da ülke dışına hareket eden kişiler ya da kişi gruplarını" (IOM, 2009, s. 8)

ifade etmektedir. Bu bağlamda,

"yerinden olma, hareketlilik ve göç gibi kavramlar, kasırga korkusuyla birkaç saatini geçici sığınma yerinde geçirenler ile deniz seviyesi yükselmesi nedeniyle toprakları tamamen yok olmuş bir toplumun hep beraber yer değiştirmesine kadar birçok durumu ima etmektedir" (Piguet vd., 2011, s. 14).

İklim göçmenleri tartışmasında en sık rastlanan tanımlardan biri ElHinnawi`nin (1985, s. 4) 〈Birleşmiş Milletler Çevre Programı (UNEP)〉 raporu için hazırladığı «varlığını tehlikeye atan ve / veya yaşam kalitesini ciddi şekilde etkileyen (doğal ve / veya insanlar tarafından tetiklenen) belirgin bir çevresel bozulma nedeniyle geleneksel yaşam ortamlarından geçici veya kalıcı olarak ayrılmak zorunda kalan insanlar» şeklindeki «çevresel mülteciler〉 tanımıdır. Castles ve Miller'a göre ise "Çevresel değişikliklerin (çölleşme, ormansızlaşma, erozyon, hava kirliliği, su kirliliği ve su baskını), doğal felaketlerin (seller, volkanlar, toprak kaymaları, depremler) ve insan kaynaklı felaketlerin (sanayi kazaları, radyoaktivite) yerinden ettiği insanlardan oluşan çevresel mülteciler" zorunlu göçmenlerin bir türüdür (Castles ve Miller, 2008, s. 146).

'Toprak bozulmas1, sel ve kurakl1k nedeniyle yerinden olan insanlar' kastedilerek birinci IPCC (1990, s. 5-10) raporunda da çevresel mülteciler terimine yer verilmiş, ikinci IPCC (1995, s. 98 ve 207) raporunda ise hem çevresel mülteciler terimine hem de deniz seviyesi altında kalacak ada sakinleri kastedilerek iklim mültecileri kavramına değinilmiştir ki bu tanımlar Myers'ın (1993, s. 752) 'kuraklık, toprak erozyonu, çölleşme ve diğer çevresel sorunlar nedeniyle kendi ülkelerinde artık geçimlerini sağlayamayan ve bazıları sınır ötesine kaçan bazıları ise ülke içinde yerinden edilmiş hale gelen insanlar' olarak tanımladığı 'çevresel mülteciler' tanımıyla benzerlik göstermektedir. Diğer taraftan Biermann ve Boas (2010, s. 67) iklim mültecilerini, iklim değişikliğinin üç etkisinden (deniz seviyesi yükselmesi, aşırı hava olayları, kuraklık ve su kıtlığı) en az biriyle ilintili olarak doğal çevrelerindeki ani ya da aşamalı değişimler nedeniyle yerleşim yerlerini acilen ya da yakın gelecekte terk etmek zorunda kalanlar şeklinde tanımlamaktadır. 
1951 Mültecilerin Statüsüne İlişkin Cenevre Sözleşmesi, 1967 Protokolü ve 1998 Yerinden Olma Konusunda Yol Gösterici İlkeler zorunlu yerinden edilme ve mülteci konularındaki kilometre taşlarıdır (Laczko ve Aghazarm, 2009, s. 391). 1951 Cenevre Sözleşmesine göre, mülteciler:

“1 Ocak 1951'den önce meydana gelen olaylar sonucunda ve 1rk1, dini, tabiiyeti, belli bir sosyal gruba mensubiyeti veya siyasi düşünceleri yüzünden, zulme uğrayacağından haklı nedenlerle korktuğu için vatandaşı olduğu ülkenin dışında bulunan ve bu ülkenin korumasından yararlanamayan, ya da söz konusu korku nedeniyle, yararlanmak istemeyen; yahut tabiiyeti yoksa ve bu tür olaylar sonucu önceden yaşadığ 1 ikamet ülkesinin dışında bulunan, oraya dönemeyen veya söz konusu korku nedeniyle dönmek istemeyen herkes"tir (UNHCR, 1951: Madde 2).

Görüldüğü üzere bu tanım çevresel nedenlerden ötürü yerinden olan insanları kapsamamakta ve onlara sığınma hakkı tanımamaktadır. Çevresel değişimler ve mülteci akımları arasındaki bağlantılar çok farklı düzeylerde tartışılmış olsa da çevresel değişim nedeniyle ortaya çıkan mültecileri temsil eden yasal bir kavram ya da kurumsallaşmış bir mekanizma bulunmamaktadır (McNamara, 2007, s. 13). Çevresel sürücüler mülteci koruması talep etmek için geçerli nedenler olarak nitelendirilmediği için Birleşmiş Milletler içerisinde mültecilere yardım etmek ve korumakla sorumlu olan Birleşmiş Milletler Mülteciler Yüksek Komiserliği (BMMYK) istatistikleri, iklimdeki değişimler nedeniyle yerlerinden olan insan gruplarını kapsamamakta, BMMYK, çevresel mültecileri yetkileri dışında kalan, meşru olmayan hareket halindeki nüfus olarak görmektedir. Bundan dolayı da çevresel mültecilere otomatik bir yardım ya da koruma sağlamamaktadır (McNamara, 2007, s. 19). "“Mülteci sözcüğü, bu tür insanların durumunun aciliyetini ve onlar için harekete geçme ve onlara yardımcı olma sorumluluğunu vurgulamak için hala sıklıkla kullanılmaktadır (Biermann ve Boas'ın yaptığı gibi)" (Faist ve Schade, 2013, s. 6) ancak, bu terimin kullanılmasının getirdiği birçok handikap mevcuttur.

Mülteci tanımının çevresel göçmenler için uygun olmamasını IOM şu şekilde açıklamaktadır: Mülteci tanımı uluslararası hukukta olukça belirgin bir anlam ifade etmektedir ve "zulüm altında olma korkusu" üzerine inşa edilmiştir. Ancak iklim değişikliğinin etkilerinin bir tür "zulüm” oluşturduğuna dair uluslararası bir anlaşmaya varmak zor olacaktır. Zira zulmü gerçekleştirenin devletle ilişkili bir kurum olduğuna dair geleneksel algı her ne kadar devlet dışı kurumları da kapsayacak şekilde genişletilmiş olsa da her zaman 
tanımlanabilir bir varlığı (entity) ifade eder. Ek olarak iklimsel ve çevresel etkiler mülteci sözleşmesinin dayandığı beş temel gerekçe (ırk, din, milliyet, sosyal bir gruba ya da siyasi görüsse üyelik) arasında yer almamaktadır. (IOM, 2014b, s. 22). Ayrıca 1951 Cenevre Sözleşmesi’ne göre zulüm, kişinin 1rk1, dini, uyruğu, siyasi görüşü veya belli bir sosyal grubun üyeliği nedeniyle gerçekleşirken, iklim değişikliği nedeniyle gerçekleşen/beklenen göç en azından sözleşmenin bu beş şartı bakımından bir ayrım ortaya koymazken sosyal sınıf gibi savunmasızlığı artırıcı özellikleri açısından tartışılabilir (Laczko ve Aghazarm, 2009, s. 398).

Benzer şekilde, Brown (2008, s. 14) mülteci teriminin kullanılmasında ortaya çıkan üç sorun olduğunu ifade etmektedir. Birincisi, mülteci olarak sınıflandırılmak, uluslararası alanda tanınmış bir sınırı geçmeyi gerektirir lakin iklim değişikliği nedeniyle yerinden olan insanların büyük bir çoğunluğunun kendi ülke sınırları içerisinde kalacağını -IDP (internally displaces people) olarak- göz önüne alırsak, tanımı ulusal sınırları aşmış kişilerle sınırlandırmak sorunun boyutunun olduğundan daha küçük görülmesine neden olabilir. İkincisi, mülteci teriminin özelliği göçe neden olan baskının sona ermesinin ardından geri dönüş hakkını vurgulayan bir terim olmasıdır. $\mathrm{Ne}$ var ki deniz seviyesi yükselmesi gibi durumlardan ötürü terim bu noktada da sorunun doğasını karşılamakta yetersiz kalmaktadır. Sonuncusu ise mevcut mülteci tanımının çevresel baskıları da kapsayacak şekilde genişletmenin mevcut uluslararası mekanizmaları ve iyi niyetleri azaltacağı endişesidir. Öte yandan çevresel göçlerin ülkeler arasından çok ülke içerisinde gerçekleşme eğiliminde olması dolayısıyla "mülteciler" yerine "ülke içerisinden yerinden edilenler"den (IDPs) söz etmek daha doğrudur. Bu bağlamda 1998 Yerinden Olma Konusunda Yol Gösterici İlkeler'i adapte etmek ya da genişletmek daha mantıklı görünmektedir (Laczko ve Aghazarm, 2009, s. 18 ve 398). Ayrıca, mülteci tanımının kabul edilmesi durumunda gelişmiş ülkelerin siyasi mültecilere sundukları korumaların aynısını iklim mültecilerine de sunmak zorunda kalacakları ve BMMYK'nın mevcut mülteci sayısıyla dahi başa çıkmakta zorlanıyor olması uluslararası toplumda mülteci tanımının genişletilmesine karşı çıkışları da beraberinde getirmektedir (Brown, 2008, s. 14).

Diğer taraftan mülteci teriminin yabancı düşmanlığı ve ırkçı perspektifleri beslediği ve son zamanlarda Avrupa ve Kuzey Amerika'nın politik söylemine gi- 
ren iklim değişikliği kaynaklı göç korkularını işaret etmesi dolayısıyla da siyasi açıdan sıkıntılı görülmektedir (Oliver-Smith, 2012, s. 1062). İlaveten sel ya da firtına gibi ani gerçekleşen iklim değişikliği etkileri sonucunda göç eden insanların evlerine geri dönmeleri söz konusu olabilirken, kuraklık ya da deniz seviyesi yükselmesi gibi yavaş başlangıçlı ve aşamalı etkiler sonucu bir geri dönüşs söz konusu olmadığı için yine "mülteci" terimi yanıltıcı olabilmektedir (Laczko ve Aghazarm, 2009, s. 398). Dahası, Oliver-Smith'in (2012, s. 1062) aktardığı üzere, çevresel değişim ve çatışma literatürünü eleştiren Hartmann (2009) "çevresel mülteci” teriminin ekonomik ve politik nedenleri doğallaştırdığı ve apolitikleştirdiğini, kurumsal tepkilerin rolünü maskelediğini, tarihsizleştirici olduğunu ve belirli nüfusların neden daha savunmasız olduğunun sebeplerini ortadan kaldırarak suçu toplumsal nedenlerden çok doğaya bıraktığını iddia etmektedir.

İklim değişikliği kaynaklı göçmenler herhangi bir uluslararası koruma rejimine tam olarak uymamakla birlikte ne mülteci hukuku ne insan hakları hukuku ne de iklim değişikliği düzenlemeleri tam olarak iklim değişikliğinin neden olduğu göçe eğilmektedir. İklim değişikliği göçmenleri hem mülteci olarak kalabilmek için gerekli görülen zulümden muzdarip değillerdir ya da başka bir deyişle uğradıkları zulüm kabul edilen zulüm tanımına uymamaktadır, hem de uluslararası hukukun bireyden çok devlete odaklanan yapısı onları daha da görünmez kılmaktadır (Nishumura, 2015, s. 114).

Zaman içerisinde söylemin "iklim mültecileri”nden "iklim göçmenleri”ne kaydığını görmek mümkündür. Birçok çalışmada "iklim mültecileri” terimi antropojenik iklim değişikliğinin sosyal ve insani sonuçlarının altını çizmek için kullanılmıştır. Bu çerçevede iklim mültecileri pay sahibi olmadıkları iklim değişikliği gerçekliğinin kurbanları olarak görülen imgelerdir. Zira çoğunlukla masum güneyli insanlar kuzeylilerin neden olduğu sera gazı emisyonlarının sonuçlarına maruz kalmaktadır. Bu anlayışta, yükselen deniz seviyeleri ya da artan doğal afetler ve çölleşme gibi iklim değişikliğinin sonuçları hem iç hem de uluslararası göçü tetiklemektedir. Çevreci sivil toplum kuruluşları, bazı akademisyenler, uluslararası örgütler ve toplumsal hareketler tarafindan kabul edilen bu görüş, iklim mültecilerinin ortaya çıkmasını, iklim değişikliğini azaltma politikalarının başarısızlığına bağlamaktadır. Süregelen eleştiriler sonucunda, bu söyleme paralel olarak, göçe iklim değişikliğine uyum stratejisi olarak vurgu yapan ve azaltma ve uyum politikalarının başarısızlığını kabul 
etmeyen “iklim göçü” anlayışı gelişmiştir. İklim değişikliğine bir çözüm olarak sunulan iklim göçü bu bağlamda yönetilebilir olduğu sürece geçerli bir strateji olarak görülmektedir (Felli, 2013, s. 344).

'Göçmen' kelimesi kısmen mülteci teriminden kaçınmak için ve döngüsel ve mevsimlik göç, yavaş başlayan değişiklikler yüzünden uzun dönemli göç ya da ani olaylara bağlı olarak kısa vadeli yerinden olma gibi çeşitli çevresel nüfus hareketlerini de kapsaması nedeniyle daha geniş bir çağrışıma sahip olduğu için kullanılmaktadır. (Faist ve Schade, 2013, s. 6). Bununla birlikte Brown (2008, s. 14) göçmen ifadesinin kaynak ülkenin “itici” niteliğindense hedef ülkenin "çekici" niteliğini daha çok vurguladığı ve uluslararası toplumun refahı için sorumlulukların azaltmasını ima etmesi nedeniyle olumsuz çağrışımlar taşıdığını ifade etmektedir.

“2008 yılında Avrupa Parlamentosu’nda Yeşil Avrupa Serbest Birliği, iklim göçü konulu bir konferans düzenlemiş ve iklim göçmeni statüsünün tanınması için bir bildiri önermiştir" (Faist ve Schade, 2013, s. 153). Daha sonrasında IOM’un (2013, s. 22): “. .. yaş̧amlarını ya da yaşam koşullarını olumsuz olarak etkileyen ani ya da aşamalı değişimlerin zorlayıcı sebeplerinden ötürü geçici ya da kalıcı olarak, ülke içinde ya da ülke dışına hareket ederek evlerinden ayrılmak zorunda kalan ya da bunu seçen kişiler ya da gruplar” şeklindeki "çevresel göçmen" tanımı hukuki ya da normatif bir amaca hizmet etmese de sorunun karmaşıklığını gidermek amacıyla oluşturulmuş olup, literatürde de sık sık kullanılmaktadır. "Çevresel göçmen” kavramının uluslararası kabul görmüş hukuki bir tanımı bulunmamakla birlikte, göç hareketinin zorunlu doğası vurgulanmak istendiğinde "çevresel olarak yerinden olan kişi”" terimi kullanılmaktadır (IOM, 2014b, s. 22). Bu tanımdan hareketle Kniveton vd. (2008, s.31), “iklim değişikliği göçmenleri”ni çevresel göçmenlerin bir alt kümesi olarak "yaşamlarını ya da yaşam koşullarını olumsuz yönde etkileyen iklim değişikliğinin bir sonucu olarak çevredeki ani ya da aşamalı değişimler nedeniyle meydana gelen zorlayıcı sebepler sonucu geçici ya da sürekli olarak bilindik evlerini terk etmek zorunda kalan ya da terk etmeyi seçen ve ülke sınırları içine ya da dışına hareket eden insanlar ya da insan grupları" şeklinde tanımlamaktadır. Buna ek olarak, ““'eko-göçmenler”, “ekolojik göç” terimleri ve doğrudan bir nedensel ilişkinin daha düşük bir derece olduğunu gösteren “iklim ile ilişkili göç” ya da "çevreye bağlı göç” gibi terimler tartışmaya dahil 
edilmiştir" (Faist ve Schade, 2013, s. 6). Son olarak, etkin eylem için her ne kadar zaruri bir aşama olsa da tüm bu tartışmalar sebebiyle yakın zamanda ortak bir tanım üzerinde anlaşmaya varılacağına dair umutlar oldukça düşüktür.

\section{Göç Etme Eyleminde Tehdit Çarpanı Olarak İklim Değişikliği}

İklim değişikliğinin deniz seviyesi yükselmesine bağlı batan adalar ya da kasırga ve firtınalar gibi uç hava olayları sonucu yaşanan tecrübeler sonucu doğrudan bazı göç şekillerine neden olabileceği, aynı zamanda halihazırda var olan birçok göç sürücüsü için katalizör görevi görebileceğine önceki bölümlerde değinilmiştir. İklim değişikliğinin tehdit çarpanı haline geldiği bu karmaşık etkileşim aşamalı bir biçimde çok daha büyük kitleleri ilgilendirmektedir.

Göç etme mecburiyetini bir taraftan arttırabilecekken bunu yapabilme kapasitesini de azaltabilecek olan iklim değişikliğine bağlı çevresel değişimlerin göç sürücüleri (ekonomik, demografik, sosyal, politik, çevresel) üzerindeki etkileri, Black ve arkadaşları tarafından "Göç ve Küresel Çevresel Değişim: Gelecekteki Zorluklar ve Fırsatlar” raporunda ortaya koyulmaya çalışılmıştır (Black vd., 2011, s. 51-52; Black vd., 2011a, s. 448). Bu raporun ardından yayınladıkları makalede de belirttikleri üzere, deniz seviyesi yükselmesi, tropik firtınalar ve siklonlarda artış, yağış rejimlerindeki değişimler, sıcaklıklarda artış ve atmosferin kimyasındaki değişimler göçü doğrudan etkileyecek olan gelişmelerdir. Diğer yandan iklim değişikliğinin göçün ekonomik, demografik, politik, sosyal ve çevresel sürücülerini etkilemek suretiyle de göç düzenlerinin değişimine dolaylı katkıda bulunduğuna dair kanıtlar gün geçtikçe artmaktadır (Black vd., 2011b, s. 8).

Her ne kadar firtına, kasırga ve hortum gibi uç hava olayları ön planda görülse de iklimde yaşanan aşamalı değişimlerin insan hareketliliği üzerindeki etkisi çok daha büyük olacaktır. Çölleşme ve kıyı erozyonu gibi kademeli ve yavaş gerçekleşen çevresel değişimler daha az dramatik görünmeleri nedeniyle pek dikkat çekmeseler de büyük miktarda insanı etkilemektedir ve uzun vadede etkilemeye de devam edecektir (Laczko ve Aghazarm, 2009, s. 15). Firtına ya da hortum gibi ani ve habersiz gerçekleşen felaketler sonucunda çok hızlı bir biçimde göç etmek gerektiği için planlama yapmak görece zordur. Ancak kuraklık gibi yavaş ve etkileri zamana yayılmış bir şekilde gerçekleşen değişimler bağlamında göç, sahip olunan imkân ve kaynakları kullanmak 
açısından bir araç olarak çok daha iyi hizmet edebilir. Yavaş başlangıçlı ve ani iklim olaylarına bağlı göçlerin ağırlıklı olarak ulusal düzeyde kırdan kıra ya da kırdan kente şeklinde, uluslararası göç açısından genel olarak en yakın sınıra doğru gerçekleşmesi muhtemeldir. Küçük Pasifik adalarının gelişmekte olan devletleri "vatansızlık" durumu söz konusu olduğu özel bir durum teşkil etmektedirler. Uzun mesafeli uluslararası göçlerin finansal kaynaklar ve sosyal ağlar gerektirmesi nedeniyle bu şekilde gerçekleşen hareketler mevcut göç düzenleri üzerinden ilerleyecektir (Laczko ve Aghazarm, 2009, s. 23).

İster ani gerçekleşen uç hava olayları şeklinde ister yavaş başlangıçlı ve uzun vadeli değişimler şeklinde gerçekleşsin, iklim değişikliğinin göç hareketleri, düzenleri ve yoğunlukları üzerinde farklı etkileri olduğu/olacağı bilinmektedir. ${ }^{6}$ Tahminler, önümüzdeki 40 y1l boyunca 25 milyon ile 1 milyar arasında insanın iklim değişikliği nedeniyle yer değiştirebileceğini söylemektedir (Laczko ve Aghazarm, 2009, s. 9). Örneğin Jakobeit ve Methmann (2007) gelecek 30 yıl içerisinde yaklaşık 150-200 milyon civarında iklim değişikliği mültecisi öngörürken, Christian Aid (2007) 2050'ye kadar bir milyar iklim değişikliği mültecisi tahmininde bulunmaktadır (akt: Kniveton vd., 2008, s. 32). Örnek vaka çalışmaları içeriğe özgü olduğu için, kapsamlı sonuçlar çıkarmak ya da göç şekilleri ve eğilimleri ile ilgili genellemeler yapmak zordur. İklim değişikliğinin gelecekte mevcut çevresel ve sosyo-ekonomik sorunları daha da şiddetlendirip şiddetlendirmeyeceği ve potansiyel geçici göç düzenlerini daha kalıcı hale getirebilme veya varış noktalarını değiştirebilme ihtimali, özellikle uluslararası göçle sonuçlanma potansiyeline götürme derecesi tam olarak bilinememektedir (Laczko ve Aghazarm, 2009, s. 24). Bu sorunun çözümüne ilişkin Piguet vd. (2011, s. 16) iki ana yöntemsel yönelim ortaya koymaktadır. Daha çok tanımlayıcı ve ileriye dönük olan birinci yöntem çevresel bozulma nedeniyle tehdit altında olan bölgelerin ve popülasyonlarının belirlenmesine ve gelecek potansiyel göçler hakkında bilgi veren bölge sakinlerinin savunmasızlık ve direnç boyutlarının bütünleşik bir değerlendirmesine odaklanır. Daha analitik olan ikinci yöntem ise diğer göç sürücüleri arasındaki belirgin çevresel bileşeni ayıklamaya çalışmakta ve yaşanan göç hareketlerinde çevresel etmenlerin rolünü ve ağırlığını sorgulamaktadır. Ayrıca, ülkeler arası karşılaştırılabilir anketlerin yoksunluğundan doğan boşluğu, 6 ülkenin

6 İklim değişikliğinin göç hareketleri, düzenleri ve yoğunlukları üzerindeki çok çeşitli etkisine ilişkin ülkeler bazında detaylı çalışmalar için bknz: IPCC, 2014b, s. 770. 
karşılaştırmalı analizini yaparak doldurma amacında olan bir diğer çalışma da Avrupa Birliği tarafından finanse edilen Göç, Çevre ve İklim Değişikliği: Politikalar için Kanıtlar (The European Union-funded Migration, Environment and Climate Change: Evidence for Policy-MECLEP) projesidir (Laczko ve Singleton, 2016, s. 2).

Küresel ısınmaya neden olan sera gazı emisyonlarından ve dolayısıyla da antropojenik iklim değişikliğinden başlıca sorumlu olan gelişmiş ülkelerken, bu gelişmenin en güçlü etkileriyle karşı karşıya olan az gelişmiş ya da gelişmekte olan ülkelerdir. IOM (2014a, s. 2) göre en çok etkilenen gruplar: toplumun marjinalize olmuş kısımları, tarıma bağımlı gruplar, en az gelişmiş ülkelerdeki, düşük seviyeli adalardaki ve kıyı bölgelerindeki nüfus ile zarardan kaçabilme ihtimali en az olanlardır. İklim değişikliğinin her bölgede olumsuz etkileri görülmektedir. Ancak özellikle ekonomilerinin büyük bir bölümü iklime duyarlı sektörlere bağımlı; beşerî, finansal ve doğal kaynakları yetersiz; kurumsal ve teknolojik kapasiteleri düşük az gelişmiş ülkeler daha savunmasız durumdadır. Bugün dahi çevre, nüfus ve göç baskısı altında bulunan bu bölgelerde durumun iklim değişikliğinin etkileri ile birlikte daha da kötüleşmesi beklenmektedir.

Diğer bir ifadeyle, iklim değişikliği kaynaklı göçlerin en çok en savunmasız ve yoksul bölgelerde yaşayanlar arasında gerçekleşeceği, ancak bunun daha çok iç göç şeklinde olacağı, yani belirli bir miktar kaynak gerektiren uluslararası göç düzeyinde gerçekleşmeyeceği öngörülmektedir. En az gelişmiş ülkelerdeki nüfuslar, daha düşük adaptasyon kapasitesi (düşük ekonomik ve sosyal sermaye) nedeniyle iklim değişikliğinden en çok etkilenenler olacaktır. Aynı durum, savunmasız coğrafi konumlarından dolayı alçakta bulunan adalar ve kıyı bölgelerindeki nüfuslar için de geçerlidir. İklim değişikliğinin en ciddi göç ve / veya yerinden olma sonuçlarını da görecek olanlar bu ülkelerdir. İklim değişikliğinin olumsuz etkileri sonucunda göç edecek olanların aslında, bunu gerçekleştirecek finansal ve enformel kaynaklara sahip olmamaları nedeniyle en yoksul kesimler olmayabileceğine de değinmek gerekmektedir. Diğer bir ifadeyle göç edememek daha büyük bir savunmasızlığın göstergesi olabilir (IOM, 2014b, s. 39). Son raporunda IPCC'nin de belirttiği üzere planlı göç için kaynaklara sahip olmayan nüfuslar, özellikle düşük gelirli gelişmekte olan ülkelerde aşırı hava olaylarına daha fazla maruz kalmaktadır. 
İklim değişikliği dolaylı olarak yoksulluk ve ekonomik şok gibi belirli sürücüler aracılığıyla şiddetli çatışmaların riskini artırabilir (IPCC, 2014a, s. 16).

Düşük gelirli gelişmekte olan ülkeler tarafindan iklim değişikliği kaynak11 göçü yönetmek için benimsenen temel çerçeve olan Ulusal Uyum Eylem Programları'nın (National Adaptation Programmes of Action-NAPAs) yapmış olduğu değerlendirmeler birçok ülkede iklim değişikliğinin göç düzenlerini ciddi manada etkileyebileceğini göstermektedir. Ülkeler, yaşam alanlarının ve geçim kaynaklarının kaybedilmesi sonucu özellikle deniz seviyesi yükselmesi, artan kuraklık, sel ve diğer çevresel tehlikelerin etkilediği tarımsal alanlardan büyük ölçekli göçlerin hızlanacağını öne sürmektedir. ${ }^{7}$

Lilleør ve Broeck (2011, s. 79), az gelişmiş ülkelerdeki iklim değişikliğinin iki temel göç sürücüsü olan gelir seviyesi ve gelir değişkenliğini nasıl etkilediği ve bunların da göçü ne yönde tetiklediğini mevcut literatürdeki ampirik verilerden hareketle değerlendirdikleri çalışmalarında iki temel sonuca ulaşmışlardır: Birincisi, göç sürücülerinin her ikisi de daha fazla göçe neden olan/olacak iklim değişikliğinden etkilenmektedir. Ancak iklim değişikliğinin gelir seviyesi üzerindeki etkilerine dair bazı ampirik kanıtlar bulunsa da gelir değişkenliği üzerindeki etkilerine ilişkin oldukça az bulgu söz konusudur ve daha çok araştırmaya gereksinim duyulmaktadır. İkincisi, iklim değişikliğinin göçün ekonomik itici güçlerini nasıl etkilediği ve göç üzerindeki etkilerinin nasıl güçlendiği veya zayıfladığı konusunda şaşırtıcı bir biçimde araştırma eksikliği vardır. Bu sonuçlara dayanarak, en az gelişmiş ülkelerdeki (LDCs-Least Developed Countries) göçün iklim değişikliğinden nasıl etkileneceğini tahmin etmenin zor olduğunu ve mevcut projeksiyonların ampirik verilere dayanmaması nedeniyle politika yapıcıları olumsuz etkileyebileceğini ifade etmektedirler.

İklim değişikliğinin etkilerinin önüne geçebilecek bilgiye ve kaynaklara sahip olan gelişmiş ülkelerde iklim değişikliğinin göçü tetiklemesinin çok muhtemel olmadığı lakin küresel güneydeki ülkelerde iklim değişikliğinin esas olarak sosyo-ekonomik ve politik sıkıntılar için bir tehdit çarpanı görevi gördüğü sonucuna varmak mümkündür (Okeowo, 2013, s. 281). Bu bağlamda Faist ve Schade (2013, s. 4)'e göre insan-çevre ilişkilerinin toplumsal inşası, doğal ve beşerî kaynakların sürdürülemez biçimde sömürülmesine destek veren toplumsal eşitsizlikler, bu eşitsizlikleri coğrafi hareketlilikle aşmaya çalışan kişilerin çabaları ve mev-

7 Bunlardan NAPA’nın hali hazırda sunduğu örnekler için bknz: Laczko ve Aghazarm, 2009, s. 362-363. 
cut savunmasızlıkların ve kaynak yoksunluğunun bazen üstesinden gelen bazense onları yeniden üreten kurumların rolü birlikte değerlendirilmelidir.

\section{Sonuç}

İnsanlığın değişen çevresel koşullara uyum sağlamak ve geçim kaynaklarının varlığını sürdürebilmek için başvurduğu en temel yöntemlerden biri göçtür. Bununla birlikte, son yirmi yılda, çevresel göçün doğası ve ölçeği değişmeye başlamıştır. Antropojenik iklim değişikliği, insani acil durumların riskini artırmakta; aşırı hava koşulları, deniz seviyesinin yükselmesi, çölleşme vb. süreçlerle çevresel bozulmanın hızlanması sonucunda nüfus hareketlerini tetiklemektedir. Ayrıca, iklim değişikliği göçmenleri bugün uluslararası hukukun da en tartışmalı konularından biridir. İklim değişikliği sonucu göç eden bireyler, uluslararası mülteci ve göç politikalarının çatlaklarından sızmakta ve iklim değişikliği sonucu göç edenler için mevcut mülteci tanımının genişletilmesi mi yoksa başka bir tanımlamanın bulunması mı gerektiği yoğun bir şekilde tartışılmaktadır. Ülkelerin ve nüfusların değişen iklime uyum sağlama yetenekleri, gelecekte çevresel göçün nasıl bir yol alacağını da büyük oranda belirleyecektir. Dahası, iklim değişikliği, çevresel bozulma ve göç arasındaki bağlantıların basit, doğrusal bir nedenselliğe sahip olduğunu düşünmek yanıltıcı olur çünkü göç ile çevre arasında oldukça karmaşık ve iç içe geçmiş bir ilişki mevcuttur. Küreselleşen dünyada, antropojenik iklim değişikliğinin sonuçları ve izlediği yol, bu karmaşık ve iç içe geçmiş ilişkiyi anlamayı ve tüm boyutlarıyla analiz etmeyi kaçınılmaz kılmaktadır.

İklim değişikliği ile ilişkili insan hareketliliğinin önemi Polonya>daki 14. İklim Zirvesi'nden bu yana giderek daha iyi anlaşılmaktadır. Bununla birlikte «iklim değişikliği kaynaklı göç, yerinden olma ve planlı yer değiştirme» ile ilgili Cancun〉da (2010) kabul edilen adaptasyon kararı ve Doha>da (2012) kabul edilen kayıp ve hasar (loss and damage) kararları göç konusunda atılan önemli adımlardır. İklim değişikliği ve göç arasındaki bağlantıyı tanımak adına atılmış bir diğer önemli adım Paris Anlaşması'nda (2015) atılmış ve tarafların, iklim değişikliği nedeniyle yerinden olmaları önlemek ve azaltmak için tavsiyeler sunması gerekliliği ortaya koyulmuştur. Antropojenik iklim değişikliği küresel çapta mevcut çevresel, ekonomik ve sosyal hassasiyetleri arttırmaktadır. Öte yandan yerel ve vakaya özgü etkenlerden bağımsız bir biçimde iklim değişikliğinin etkilerine odaklanmanın, üretilen politikalarda sapmalara yol açabileceği göz ardı edilmemelidir. 
İklim değişikliğinin firtınalar ve seller gibi ani başlangıçlı felaketlerin sıklı$\breve{g} 1$ ile şiddetini ve kuraklık gibi yavaş ilerleyen felaketlerin etkilerini arttıracağ1 ayrıca çölleşme, okyanus asitlenmesi ve erozyon gibi aşamalı çevresel bozulma süreçlerini daha da kötüleştireceği bilinmektedir. Deniz seviyesi yükselmesi ve buzul erimesi gibi yükselen sıcaklıklarla bağlantılı bazı olaylar, yavaş ve aniden ortaya çıkan etkilerle birleşecektir. En çok kademeli çevresel bozulmanın uzun vadede çevresel göçlere neden olması beklenirken, bu olguların tümünün büyük ölçekli nüfus hareketlerine neden olacağı görülmektedir. İklim değişikliği sonucunda meydana gelecek yahut artacak olan yavaş başlangıçlı ve ani felaketlerin göç bağlamında farklı sonuçlara yol açabileceği ve bu gibi durumlarda göçün kimi zaman gerekli, kimi zaman engellenmesi gereken, kimi zaman ise meşru uyum stratejisi olarak ortaya çıkabileceği görülmektedir. Bu noktada müşterek yerel, ulusal ve uluslararası politikaların belirlenmesi ve uygulanması büyük önem taşımaktadır.

Yine birçok durumda olduğu gibi burada da göçün bir taraftan neden olduğu zarar ve acılar dolayısıyla bir zorluk mu yoksa üstlenebileceği adaptasyon işlevi nedeniyle bir çeşit çözüm mü olduğu tartışma konusudur. Bu bağlamda "adaptasyon" (adaptation), "savunmasızlık" (vulnerability), "dayanıklılık" (resilience), "iklim adaleti” (climate justice) ve "sürdürülebilir kalkınma" (sustainable development) önemli ve geliştirilmeye açık kavramlardır. "İklim mültecileri”, "çevresel mülteciler", "iklim göçmenleri” vs. şeklinde giden bir dizi tasnif çabasına rağmen hala yasal mevzuattaki belirsizlikler nedeniyle, iklim değişikliğinden etkilenecek toplumları da kapsayan geniş ve katılımcı süreçler oluşabilmesi adına küresel inisiyatif ve iştirakler büyük önem taşımaktadır. En büyük riski az gelişmiş ve gelişmekte olan ülkelerin taşıdığını göz önünde bulundurarak, yerel düzeyde danışma, bilgilendirme, kapasite geliştirme vb. çalışmaların güçlendirilmesi kuşkusuz öncelikli eylemlerden olmalıdır. 


\section{Kaynakça/References}

Biermann, F. ve Boas, I. (2010). Preparing for a Warmer World: Towards A Global Governance System to Protect Climate Refugees. Global Environmental Politics, 10(1), 60-88.

Black, R., Bennett, S. R., Thomas, S. M. ve Beddington, J. R. (2011). Climate Change: Migration As Adaptation. Nature, 478(7370), 447-449.

Black, R., Adger, W.N., Arnell, N., Dercon, S., Geddes, A. ve Thomas, D. (2011a). Migration and Global Environmental Change: Future Challenges and Opportunities. Final Project Report. The Goverment Office for Science, London. http://eprints.soas.ac.uk/22475/1/111116-migration-and-global-environmental-change.pdf (erişim tarihi: 15.03.2016)

Black, R., Adger, W. N., Arnell, N. W., Dercon, S., Geddes, A. ve Thomas, D. (2011b). The Effect of Environmental Change on Human Migration. Global Environmental Change, 21, 3-11.

Brown, O. (2008). Migration and Climate Change. International Organization for Migration, IOM Migration Research Series, No: 31, Switzerland.

Castles S. ve Miller M. J. (2008). Göçler Çağı: Modern Dünyada Uluslararası Göç Hareketleri. (Çev. B. Uğur Bal ve İ. Akbulut). Bilgi Üniversitesi Yayınları, İstanbul.

Dun, O. ve Gemenne, F. (2008). Defining 'Environmental Migration'. Forced Migration Review, 31 (October), 10-11. http://ro.uow.edu.au/cgi/viewcontent. cgi? article $=2406 \&$ context

=sspapers (erişim tarihi: 07.02.2017).

Faist, T. ve Schade, J. (ed.) (2013). Disentangling Migration and Climate Change. Methodologies, Political Discourses and Human Rights. Springer. DOI 10.1007/978-94007-6208-4.

Felli, R. (2013). Managing Climate Insecurity by Ensuring Continuous Capital Accumulation: 'Climate Refugees' and 'Climate Migrants'. New Political Economy, 18:3, 337-363, DOI: 10.1080/13563467.2012.687716 Erişim: http://dx.doi.org/10.1080/135 63467.2012 .687716 .

Gibb, C. ve Ford, J. (2012). Should The United Nations Framework Convention on Climate Change Recognize Climate Migrants? Environmental Research Letters, 7(4), 045601.

Hulme, M. (2016). İklim Değişikliği Konusunda Neden Anlaşamıyoruz? M. Özenç (Çev.). Alfa Bilim, İstanbul.

IOM, (2009). Göç Terimleri Sözlüğü. Uluslararası Göç Hukuku. Uluslararası Göç Örgütü, No:18, İsviçre. http://www.goc.gov.tr/files/files/goc_terimleri_sozlugu.pdf (erişim tarihi: 05.12.2016).

IOM, (2013). Wide Survey on Migration, Enviroment and Climate Change, Switzerland. IOM, (2014a). Perspectives on Migration, Environment and Climate Change, Geneva, Switzerland. http://publications.iom.int/system/files/pdf/meccinfosheet_climatechange activities.pdf (erişim tarihi: 19.07.2016). 
IOM, (2014b). IOM Outlook on Migration, Environment and Climate Change. IOM, İsviçre. DOI: http://dx.doi.org/10.18356/9ba951ac-en.

IOM, (2017). World Migration Report 2018. Editors: Marie McAuliffe (IOM) and Martin Ruhs (University of Oxford). International Organization for Migration and The UN Migration Agency, Switzerland. https://publications.iom.int/system/files/pdf/ wmr_2018_en.pdf (erişim tarihi: 20.10.2018).

IOM ve GMDAC, (2018). Global Migration Indicators. Global Migration Data Analysis Centre (GMDAC) International Organization for Migration, Elisa Mosler Vidal \& Jasper Dag Tjaden under the supervision of Frank Laczko (IOM GMDAC) https:// publications.iom.int/system/files/pdf/global_migration_indicators_2018.pdf (erişim tarihi: 20.10.2018).

IPCC, (1990). First Assesment Report (FAR). Climate Change: The IPCC Impacts Assessment. W.J. McG. Tegart, G.W. Sheldon and D.C. Griffiths (eds.). Australian Government Publishing Service, Camberra, Australia. 294 pp. https:/www.ipcc.ch/ publications_and_data/publications_ipcc_first_assessment_1990_wg2.shtml (erişim tarihi: 18.07.2016)

IPCC, (1995). Climate Change 1995: Economic and Social Dimensions of Climate Change Contribution of Working Group III to the Second Assesment Report of the Intergovermental Panel on Climate Change. Editors J.J. Houghton, L.G. Meiro Filho, IS. A. Callander, N. Harris, A. Kattenberg and K. Maskell. (ISBN 0-521-56433-6 Hardback; 0-521-56436-0 Paperback) http://www.ipcc.ch/publications_and_data/publications and_data_reports.shtml (erişim tarihi: 19.10.2018).

IPCC, (2014a). Summary for policymakers. In: Climate Change 2014: Impacts, Adaptation, and Vulnerability. Part A: Global and Sectoral Aspects. Contribution of Working Group II to the Fifth Assessment Report of the Intergovernmental Panel on Climate Change [Field, C.B., V.R. Barros, D.J. Dokken, K.J. Mach, M.D. Mastrandrea, T.E. Bilir, M. Chatterjee, K.L. Ebi, Y.O. Estrada, R.C. Genova, B. Girma, E.S. Kissel, A.N. Levy, S. MacCracken, P.R. Mastrandrea, and L.L. White (eds.). Cambridge University Press, Cambridge, United Kingdom and New York, NY, USA, ss. 1-32.

IPCC, (2014b). IPCC's Working Group II Contribution to the Fifth Assessment Report, released in March 2014: IPCC 5AR, WG2, Volume 1, Chapter 12. (2014) http://www. ipcc.ch/report/ar5/wg2/ (erişim tarihi: 05.02.2017).

IPCC, (2018). Special Report on Global Warming of $1,5^{\circ} \mathrm{C}$, released in October, 2018: Approval Session, Chapter 1, IPCC SR1.5. http://www.ipcc.ch/report/sr15/ (erişim tarihi: 19.10.2018).

Kniveton, D., Schmidt-Verkerk, K., Smith, C. ve Black, R. (2008). Climate Change and Migration: Improving Methodologies to Estimate Flows. International Organization for Migration, IOM Migration Research Series, No: 33, Switzerland.

Laczko, F.ve Aghazarm, C. (Eds.). (2009). Migration, Environment and Climate Change: Assessing the Evidence (pp. 7-40). Geneva: International Organization for Migration. 
Laczko, F. ve Singleton, A. (2016). Data on Environmental Migration: How Much Do We Know? Global Migration Data Analysis Centre (GMDAC) Data Briefing Series, Germany. https://publications.iom.int/system/files/pdf/gmdac_data_briefing_series issue2.pdf (erişim tarihi: 10.03.2017).

Lilleør, H. B. ve Van den Broeck, K. (2011). Economic Drivers Of Migration And Climate Change In LDCs. Global Environmental Change, 21, 70-81.

McAdam, J. (2011). Climate Change Displacement and International Law: Complementary Protection Standards. Legal and Protection Policy Research Series. Division of International Protection United Nations High Commissioner for Refugees (UNHCR).

McLeman, R. (2013). Developments in Modelling of Climate Change-Related Migration. Climatic Change, 117(3), 599-611.

McLeman, R. ve Smit, B. (2006). Migration as an Adaptation to Climate Change. Climatic Change, 76(1-2), 31-53.

McNamara, K. E. (2007). Conceptualizing Discourses on Environmental Refugees at The United Nations. Population and Environment, 29(1), 12-24.

Myers, N. (1993). Environmental Refugees in a Globally Warmed World. BioScience, 43(11), 752-761. https://www.jstor.org/stable/pdf/1312319.pdf (erişim tarihi: 19.10.2018).

Nicholson, C. (2014). Climate Change and the Politics of Causal Reasoning: The Case of Climate Change and Migration. The Geographical Journal, 180(2), 151-160, doi: 10.1111/geoj.12062.

Nishimura, L. (2015). 'Climate Change Migrants': Impediments to a Protection Framework and the Need to Incorporate Migration into Climate Change Adaptation Strategies. International Journal of Refugee Law, 27(1), 107-134 doi: 10.1093/ijrl/eev002.

Okeowo, D. (2013). Examining the Link: Climate Change, Environmental Degradation and Migration. Environmental Law Review; 2013, 15(4), 273-289.

Oliver-Smith, A. (2012). Debating Environmental Migration: Society, Nature and Population Displacement in Climate Change. Journal of International Development J. Int. Dev. 24, 1058-1070 Published online in Wiley Online Library (wileyonlinelibrary. com) DOI: 10.1002/jid.2887.

Piguet, E., Pécoud, A. ve De Guchteneire, P. (2011). Migration and Climate Change: An Overview. Refugee Survey Quarterly, 30(3), 1-23.

UNHCR. (1951). UN Refugee Agency. Convention and Protocol Relating to the Status of Refugees. 